Atıf için / For Citation: A. Erkişi, G. Sürücü, "A theoretical study on electronic behavior and mechanical properties of ferromagnetic manganese selenide: $\mathrm{AgMn}_{2} \mathrm{Se}_{4}$ ", Süleyman Demirel Üniversitesi Fen Edebiyat Fakültesi Fen Dergisi, 16(2), 339-348, 2021.

Araştırma Makalesi

\title{
A Theoretical Study on Electronic Behavior and Mechanical Properties of Ferromagnetic Manganese Selenide: $\mathrm{AgMn}_{2} \mathrm{Se}_{4}$
}

\author{
Aytaç ERKIŞİं ${ }^{* 1}$ Gökhan SÜRÜCÜ ${ }^{2,3}$ \\ ${ }^{1}$ Pamukkale University, Department of Physics, 20070, Denizli, Turkey \\ ${ }^{2}$ Middle East Technical University, Department of Physics, 06800, Ankara, Turkey \\ ${ }^{3}$ Ahi Evran University, Department of Electric and Energy, 40100, Kirsehir, Turkey \\ *corresponding authore-mail: aerkisi@pau.edu.tr
}

(Received: 28.05.2021, Accepted: 29.06.2021, Published: 25.11.2021)

\begin{abstract}
In this study, the electronic behavior and mechanical properties of the ferromagnetic chalcospinel manganese-based selenide $\left(\mathrm{AgMn}_{2} \mathrm{Se}_{4}\right)$ which crystallized in face centered cubic structure with space group $F d \overline{3} m$ and space number 227, were investigated. All ab initio calculations were carried out by Generalized Gradient Approximation (GGA) under spin polarization. For this composition, three different type magnetic orders were considered to detect the most stable magnetic character. For the given composition, the results of the computations indicate its ferromagnetic nature since this compound has a lower ground state energy in this magnetic order than in other magnetic phases. After determining the most energetically stable magnetic phase, the electronic behavior in this magnetic arrangement was examined. The observed electronic band structure under spin polarization of this compound shows that this selenide system is almost half-metallic material due to having small band gap $\left(\mathrm{E}_{\mathrm{g}}=0.09 \mathrm{eV}\right)$ in the minority spin state. In addition, the mechanical stability was determined with the help of elastic constants which were also employed to determine the mechanical characteristics of this compound.
\end{abstract}

Key words: Half-metallic, Ferromagnet, Density functional theory, Chalcogenide, Mechanical properties

\section{Ferromanyetik Manganez Selenyumun Elektronik Davranışı ve Mekaniksel Özellikleri Üzerine Teorik Bir Çalışma: $\operatorname{AgMn}_{2} \mathrm{Se}_{4}$}

Öz: Bu çalışmada $F d \overline{3} m$ uzay grubu ve 227 uzay numarası ile yüz merkezli kübik yapıda kristalleşen ferromanyetik kalgospinel manganez bazlı selenidin $\left(\mathrm{AgMn}_{2} \mathrm{Se}_{4}\right)$ elektronik davranışı ve mekanik özellikleri incelenmiştir. Tüm başlangıç hesaplamaları, spin polarizasyonu altında Genelleştirilmiş Gradient Yaklaşımı (GGY) ile gerçekleştirildi. Söz konusu kompozisyon için hesaplamaların sonuçları onun ferromanyetik doğasına işaret etmektedir çünkü bu bileşik bu manyetik düzende diğer manyetik fazlarda olduğundan daha düşük taban durumu enerjisine sahiptir. Enerjitik olarak en kararlı manyetik faz tespit edildikten sonra bu manyetik düzendeki elektronik davranış incelenmiştir. Bu bileşiğin spin polarizasyon altında gözlenen elektronik bant yapısı azınlık spin durumunda küçük bir bant aralığına $\left(E_{b}=0.09 \mathrm{eV}\right)$ sahip olması nedeniyle bu selenid sistemin neredeyse yar1-metalik bir malzeme olduğunu göstermektedir. Ek olarak, elastik sabitlerden yararlanılarak mekaniksel kararlılık belirlenmiş ve bu sabitler kullanılarak bu bileşiğin mekaniksel özellikleri elde edilmiştir.

Anahtar kelimeler: Yarı-metalik, Ferromanyetik, Yoğunluk fonksiyonel teorisi, Kalgonit, mekaniksel özellikler

Aytac ERKİİ, aerkisi@ pau.edu.tr, ORCID: https://orcid.org/0000-0001-7995-7590

Gökhan SÜRÜCÜ, thesurucu@gmail.com, ORCID: https://orcid.org/0000-0002-3910-8575 


\section{Introduction}

For possible technological and industrial applications, the understanding of some physical properties of materials, especially electronic and mechanical properties, have been interest of material scientists for decades. The experimental or hypothetical discovery of new half-metallic materials is valuable importance, especially for spintronic applications. In this regard, the physical properties of ferromagnetic halfmetallic compounds such as chalcogenide chromium spinels given by the general formula $\mathrm{ACr}_{2} \mathrm{Ch}_{4}(\mathrm{Ch}=\mathrm{S}$, Se and $\mathrm{Te})$ in which element $\mathrm{A}$ is usually chosen from transition metals, has been the focus of attention for scientists for a long time [1-6]. The primitive cell of these compounds, also known as spinel chalcogenides, consists of 14 atoms and matches the space group $F d \overline{3} m$ and the space number 227 [1-3].

There are many experimental and theoretical studies in the literature on $\mathrm{ACr}_{2} \mathrm{Ch}_{4}(\mathrm{Ch}$ $=\mathrm{S}, \mathrm{Se}$ and $\mathrm{Te}$ ) type compounds due to their half-metallic or semiconducting behavior. One of them is the theoretical study investigating the dielectric properties and semiconductor electronic nature of ferromagnetic chalcospinel $\mathrm{CdCr}_{2} \mathrm{~S}_{4}$ compound [2]. In another theoretical investigation, the electronic and magnetic behavior of spinel $\mathrm{CdCr}_{2} \mathrm{Te}_{4}$ was determined by ab initio calculations [3]. In a study, the ferromagnetic nature of $\mathrm{CdCr}_{2} \mathrm{~S}_{4}$ compound was examined experimentally. In the related study, the heat capacity at low temperature was measured and the magnetization measurements of this compound was carried out [7]. In other experimental studies, $\mathrm{CuCr}_{2} \mathrm{Te}_{4}$ compound was reported as a ferromagnetic metal at Curie temperature around $300 \mathrm{~K}$. Also, $\mathrm{CuC}_{2} \mathrm{O}_{4}$ compound was reported as a ferromagnetic metal at Curie temperature around $300 \mathrm{~K}$ in another studies [8-11]. In this context, the main focus of this study is the addition of a new compound to the chalcospinel family due to the observation of halfmetallic and ferromagnetic behaviors in $\mathrm{AgMn}_{2} \mathrm{Se}_{4}$ compound, which are important in technology.

In this study, due to the fact that the half-metallic compounds can be used in spintronic applications, the electronic behavior and some mechanical properties of new manganese-based selenide $\mathrm{AgMn}_{2} \mathrm{Se}_{4}$ for the stable magnetic phase was investigated. The observed electronic band structure in the most stable ferromagnetic phase using GGA approach, is nearly half-metallic and it could have great importance in terms of technology and industry. The addition of a new compound to chalcospinel family is significant since the $\mathrm{AgMn}_{2} \mathrm{Se}_{4}$ compound has a half-metallic behavior and can be used in possible future spintronic applications. As far as we have examined from the literature, there is no detailed study on the magnetic and electronic natures and mechanical properties of this compound yet.

\section{Material and Method}

In this computational study, the projector augmented wave (PAW) method [12] under the VASP (Vienna Ab initio Simulation Package) [13-14] algorithm was utilized for $a b$ initio calculations [15-16]. To describe exchange-correlation effects in electron-electron interaction, Perdew-Burke-Ernzerhof (PBE) [17] type ultra-soft pseudopotentials under the framework of Generalized Gradient Approximation (GGA) were used. The electronic configurations of $\mathrm{Ag}, \mathrm{Mn}$, and $\mathrm{Se}$ atoms in our composition are as follows: $5 s^{1} 4 d^{10}, 3 d^{6} 4 s^{1}$, and $4 s^{2} 4 p^{4}$, respectively. The optimization process which for obtaining optimal lattice parameter and suitable atomic positions in primitive cell of the mentioned system, was realized by using automatically generated $10 \times 10 \times 10$ Monkhorst-Pack scheme [18] giving 110 k-points. During the calculations, the kinetic 
energy cutoff value was fixed as $700 \mathrm{eV}$. The atoms in the primitive cell of this system were relaxed with the help of quasi-Newton method which was utilized for optimizing atoms until the forces on each atom less than $10^{-8} \mathrm{eV} / \AA$. Also, to compute Kohn-Sham equations iteratively, the energy convergence criteria was taken as $10^{-9} \mathrm{eV}$. After deciding on the appropriate magnetic order for the system in this study, the electronic character and some mechanical properties were determined.

\section{Results}

Firstly, to detect relaxed atomic positions and optimized lattice parameter for the primitive cell of chalcospinel manganese-based selenide $\left(\mathrm{AgMn}_{2} \mathrm{Se}_{4}\right)$, the optimization process was carried out. Then, the stable magnetic order, electronic character and also mechanical stability and anisotropy were examined for this system having face centered cubic structure with space group $F d \overline{3} m$ and space number 227 . In this composition, two silver atoms $(A g)$ were located at the $16 \mathrm{~d}(0.5,0.5,0.5)$ octahedral sites whereas four manganese atoms $(M n)$ were positioned at the $8 \mathrm{a}(0.125,0.125,0.125)$ tetrahedral sites. The eight selenium ions $(\mathrm{Se})$ in this normal spinel system were placed at the $32 \mathrm{e}(u, u$, $u$ ) where $u$ is internal parameter. In Figure 1, the primitive cell which have 14 atoms, of this composition is illustrated as three-dimensional crystallographic shape.

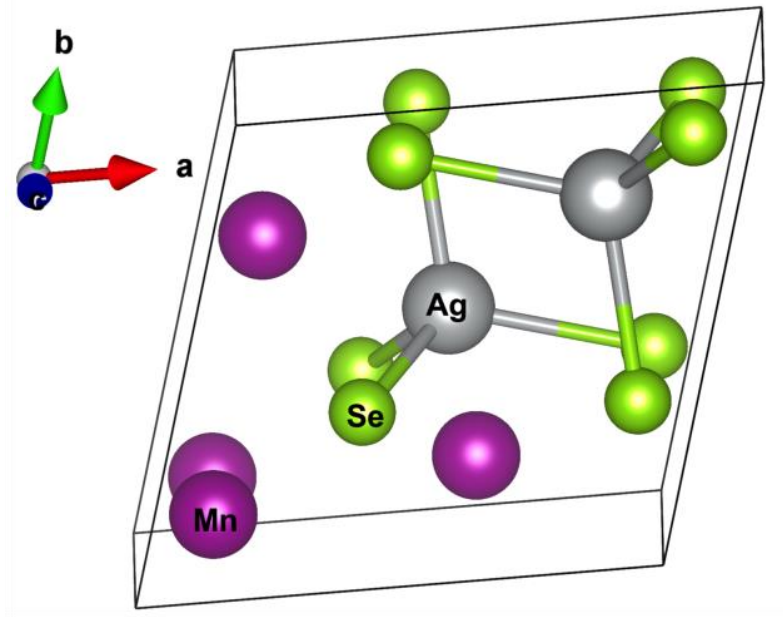

Figure 1. The three-dimensional crystallographic shape of the primitive cell which is designed by 14 atoms, of $\mathrm{AgMn}_{2} \mathrm{Se}_{4}$ compound.

\subsection{The Suitable Magnetic Phase and the Obtained Structural Parameters}

In this study, in order to decide the most stable magnetic phase of this system, it was considered three different type magnetic order as ferromagnetic (FM), antiferromagnetic $(\mathrm{AFM})$ and paramagnetic (PM). Then, for each type, the formation energies $\left(\Delta E_{f}\right)$ which is calculated to understand the thermodynamic stability or synthesizability of a solid for technological applications, was calculated from the internal energy changes [19] as presented in Equation 1:

$$
\Delta E_{f}=E_{A g M n_{2} S e_{4}}-\left(E_{A g}^{b u l k}+2 E_{M n}^{b u l k}+4 E_{S e}^{b u l k}\right)
$$

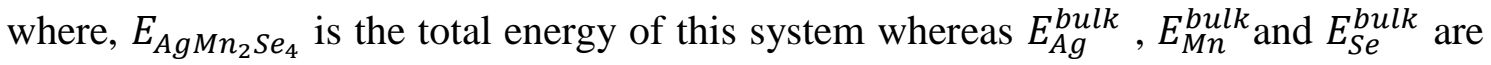
the ground state energies of $\mathrm{Ag}, \mathrm{Mn}$ and $\mathrm{Se}$ single crystals per atom. Because of the 
negative formation energy values as listed in Table 1 it can be concluded that this system is a thermodynamically stable and synthesizable material. Also, the ferromagnetic type is the energetically most favorable type for this compound since this type has the lowest formation energy value among these types. Also, the lattice parameters of these types are listed in Table 1 and the ferromagnetic type has the highest lattice parameter among these types.

Table 1. For different type magnetic phases, the obtained optimal lattice parameters (a in $\AA$ ) and the formation energies $\left(\Delta E_{f}\right.$ in $\left.\mathrm{eV}\right)$ of $\mathrm{AgMn}_{2} \mathrm{Se}_{4}$ compound.

\begin{tabular}{ccc}
\hline Compound & $\mathrm{a}(\AA)$ & $\Delta \mathrm{E}_{\mathrm{f}}$ (eV/f.u.) \\
\hline & $5.379(\mathrm{FM})$ & $-2.361(\mathrm{FM})$ \\
\cline { 2 - 3 } $\mathrm{AgMn}_{2} \mathrm{Se}_{4}$ & $5.353(\mathrm{AFM})$ & $-2.339(\mathrm{AFM})$ \\
\cline { 2 - 3 } & $5.178(\mathrm{PM})$ & $-1.346(\mathrm{PM})$ \\
\hline
\end{tabular}

For this composition, after the optimization process was operated and the formation energies were calculated, with the help of the ground state energies and the unit cell volumes, energy-volume graphics was plotted by fitting the Vinet equation of state [20] as shown in Figure 2. The obtained ground state energies were well-converged and the asymptotic errors in fitting process were around one percent.

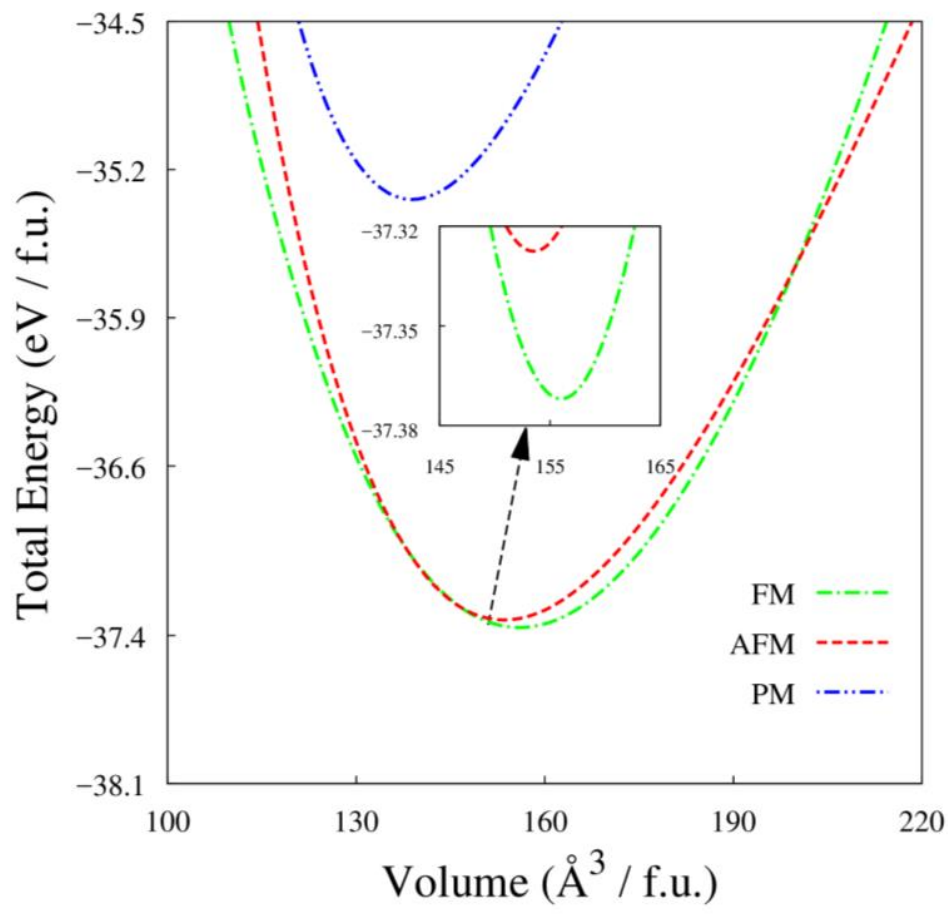

Figure 2. The plotted energy-volume graphics for each of magnetic order of $\mathrm{AgMn}_{2} \mathrm{Se}_{4}$.

The energy-volume plots for the mentioned chalcospinel manganese-based selenide emphasizes that the paramagnetic and the antiferromagnetic phases are less favorable for this composition due to having larger ground state energy values than ferromagnetic phase. As can be seen from this figure, this compound is stable in the ferromagnetic phase as also indicated with the calculated formation energies. Consequently, the system in question is important for materials science as it has a ferromagnetic character. 


\subsection{The Observed Half-metallic Character of $\mathrm{AgMn}_{2} \mathrm{Se}_{4}$ Selenide}

To discover the electronic character of the chalcospinel manganese-based $\mathrm{AgMn}_{2} \mathrm{Se}_{4}$ selenide, the electronic band structure and the total density of states (TDOS) were calculated under spin effect using the GGA approximation and drawn along the high symmetry directions for both majority and minority spin states. The plotted band graph with total density of states is presented in Figure 3. It is clearly seen from this figure that, the chalcospinel manganese-based selenide $\left(\mathrm{AgMn}_{2} \mathrm{Se}_{4}\right)$ having ferromagnetic character, behaves as a nearly half-metallic material due having a small band gap $\left(\mathrm{E}_{\mathrm{g}}=\right.$ $0.09 \mathrm{eV}$ ) in minority spin state. This band gap observed in the minority spin state is a direct band gap at $\Gamma$ point.

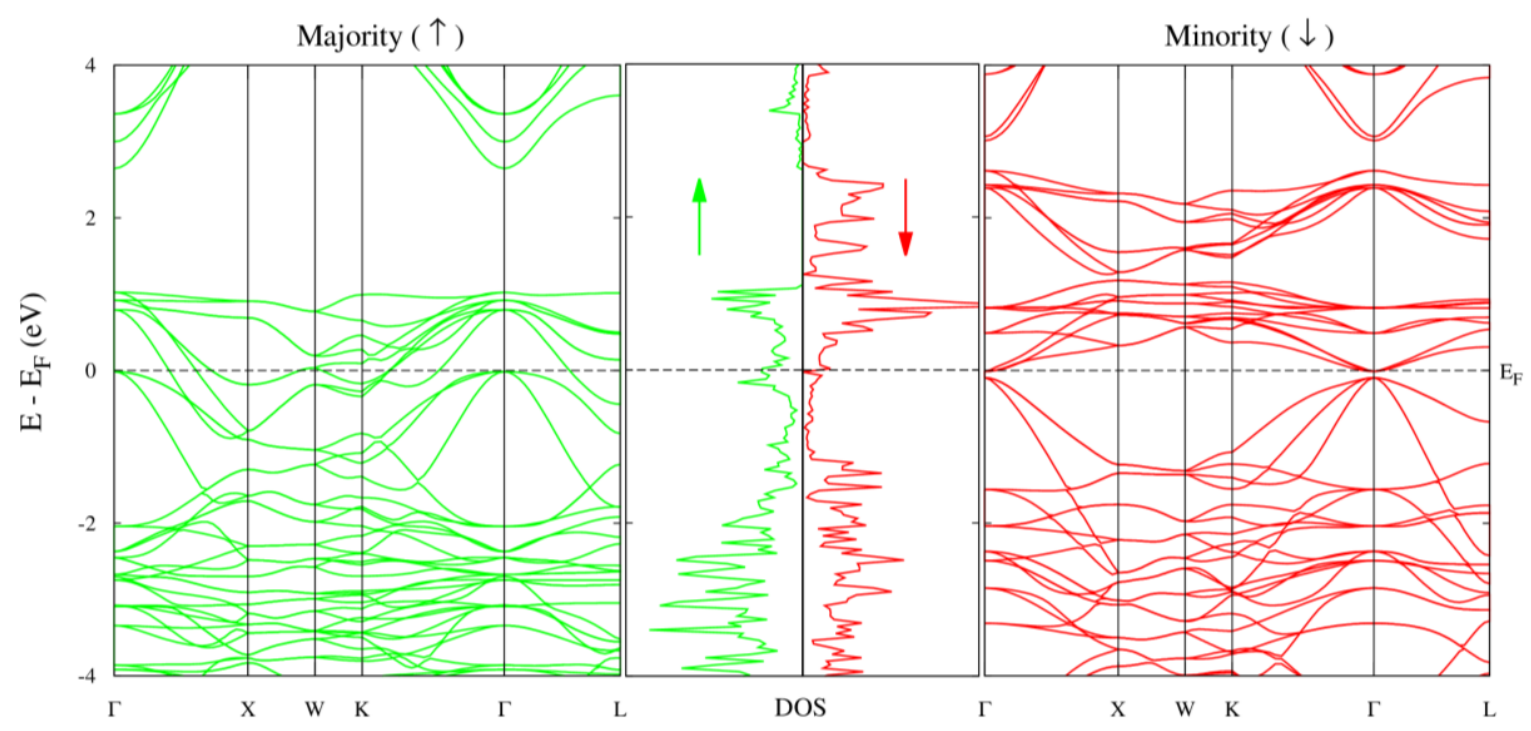

Figure 3. The electronic band structure under spin effect and the TDOS of $\mathrm{AgMn}_{2} \mathrm{Se}_{4}$ compound.

The plotted orbital projected partial density of states for atoms in this system and the total density of states are presented in Figure 4. It is clearly seen from this figure that, the $4 p$ - orbitals of the selenium $(\mathrm{Se})$ atoms are dominant both in the valence band and in the conduction band whereas the $d$-orbitals of manganese $(M n)$ atoms are dominant especially in the conduction band close to Fermi energy. The hybridizations between $d$ orbitals of manganese $(\mathrm{Mn})$ atoms and $p$ - orbitals of selenium $(\mathrm{Se})$ atoms are noticeable in the region of this selenide composition close to the Fermi energy level of the conduction band (between about $0 \mathrm{eV}$ and $1.1 \mathrm{eV}$ ). Furthermore, in the valence band nearly between $-4 \mathrm{eV}$ and $-1.5 \mathrm{eV}$, the hybridizations are seen between $d$-orbitals of silver $(\mathrm{Ag})$ and manganese $(\mathrm{Mn})$ atoms and $p$ - states of selenium $(\mathrm{Se})$ atoms. Also, it can be clearly understood that the filled $s$ - orbitals in this composition, given by dashed red lines in the graph in question, have very low-density states around the Fermi energy, so they do not have a significant effect on the bonding properties. In addition, it can be said that $p$-orbitals of silver $(A g)$ and manganese $(M n)$ atoms have not dominant role about the half-metallicity nature of $\mathrm{AgMn}_{2} \mathrm{Se}_{4}$ selenide. In this regard, the half-metallic behavior of this chalcospinel manganese-based selenide $\left(\mathrm{AgMn}_{2} \mathrm{Se}_{4}\right)$ can be chiefly determined by $d$ - orbitals of manganese $(\mathrm{Mn})$ atoms and $p$ - orbitals of selenium $(\mathrm{Se})$ atoms and hybridizations between them. 


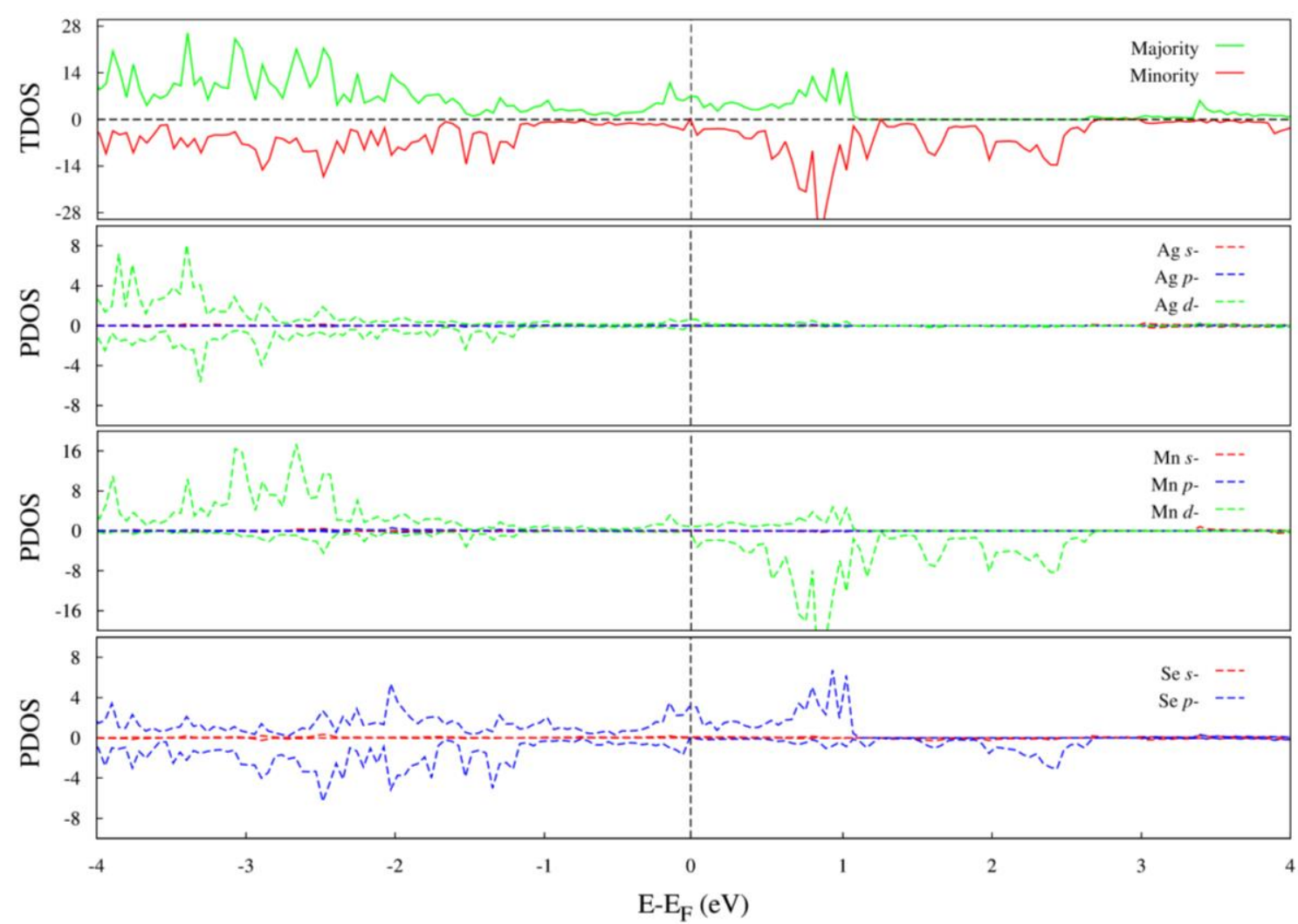

Figure 4. The total (TDOS) and the partial density of states (PDOS) of $\mathrm{AgMn}_{2} \mathrm{Se}_{4}$ compound.

The computed total and partial magnetic moments of this compound show that manganese atoms play the leading role in its ferromagnetic nature. Also, as a typical character of half-metallic systems, the total magnetic moment is close to integer value, as seen in Table 2.

Table 2. The computed total magnetic moment $\left(\mu_{\text {tot }}\right)$ of the ferromagnet $\mathrm{AgMn}_{2} \mathrm{Se}_{4}$ compound and the total magnetic moments $\left(\mu_{\text {atom }}\right)$ of $A g, M n$, and $S e$ atoms in this composition.

\begin{tabular}{ccc} 
Compound & $\mu_{\text {tot }}\left(\mu_{\mathrm{B}}\right)$ & $\mu_{\text {atom }}\left(\mu_{\mathrm{B}}\right)$ \\
\hline & & $\mu_{\mathrm{Ag}}=-0.044$ \\
$\mathrm{AgMn}_{2} \mathrm{Se}_{4}$ & 13.270 & $\mu_{\mathrm{Mn}}=14.049$ \\
& & $\mu_{\mathrm{Se}}=-0.735$ \\
\hline
\end{tabular}




\subsection{The Mechanical Properties of $\mathrm{AgMn}_{2} \mathrm{Se}_{4}$ Selenide}

The atomic bonding type of a solid crystal have a key role in its elasticity and it is so important for technological and industrial applications. Also, a solid that is mechanically stable is more preferred in such applications. Therefore, elastic constants that can be calculated using the stress-strain approach [21] under the ab initio method can be used to estimate the type of bonding, ductility, and also mechanical stability of a crystal. The mechanical characteristic of a cubic crystal can be understood from three independent elastic constants $\left(C_{11}, C_{12}\right.$ and $\left.C_{44}\right)$ [22]. The calculated constants for $\mathrm{AgMn}_{2} \mathrm{Se}_{4}$ selenide are tabulated in Table 3.

Table 3. The computed elastic constants $\left(C_{i j}\right.$ in $\left.G P a\right)$ and Cauchy pressure $\left(C_{p}=C_{12}-C_{44}\right.$ in $\left.G P a\right)$ of $\mathrm{AgMn}_{2} \mathrm{Se}_{4}$ compound.

\begin{tabular}{ccccc}
\hline Compound & $C_{11}(\mathrm{GPa})$ & $C_{12}(\mathrm{GPa})$ & $C_{44}(\mathrm{GPa})$ & $C_{p}(\mathrm{GPa})$ \\
\hline $\mathrm{AgMn}_{2} \mathrm{Se}_{4}$ & 73.11 & 53.29 & 22.76 & 30.53 \\
\hline
\end{tabular}

To designate mechanical stability for a material, the Born-Huang criteria [22] are usually used. In Equation 2, the mechanical stability criteria of a material which is crystallized in cubic structure, are given.

$$
C_{11}-C_{12}>0, \quad C_{11}+2 C_{12}>0, \quad C_{11}>0 \text { and } C_{44}>0
$$

It can be easily deduced that this system has mechanical stability due to satisfy the given criteria in above. The Cauchy pressure [23] as can be calculated $C_{p}=C_{12}-C_{44}$, can give an idea about brittleness of a crystal. When this pressure is greater than zero, the material can be predicted to be ductile. According to this definition, it can be said that the $\mathrm{AgMn}_{2} \mathrm{Se}_{4}$ system is a ductile material. Because of this feature, this material is of industrial importance because ductile materials can absorb more energy and elastically deform without fracturing easily.

Many mechanical properties of a material, such as ductility, brittleness or mechanical resistance, are technologically so important. In this respect, the mechanical properties of the system discussed in this study, were investigated. To be able to predict some mechanical parameters such as bulk $(B)$, Young's $(E)$ and shear $(G)$ modulus, also Pugh's $(B / G)$ and Poisson's $(\sigma)$ ratios and anisotropy shear factor $(A)$, it can be employed the elastic constants previously calculated. For $\mathrm{AgMn}_{2} \mathrm{Se}_{4}$ compound, the predicted some mechanical properties are given in Table 4 . The upper and lower limits and the average value of the bulk $(B)$ and shear $(G)$ modulus, which are among these properties, were estimated with the help of Voigt [24], Reuss [25] and Hill [26] approaches. The formulas employed according to these approaches are given in Equations 3-6, respectively.

$$
\begin{aligned}
B_{V} & =B_{R}=\frac{C_{11}+2 C_{12}}{3} \\
G_{V} & =\frac{C_{11}-C_{12}+3 C_{44}}{5}
\end{aligned}
$$




$$
\begin{gathered}
G_{R}=\frac{5\left(C_{11}-C_{12}\right) C_{44}}{4 C_{44}+3 C_{11}-3 C_{12}} \\
B_{H}=\frac{B_{V}+B_{R}}{2} ; G_{H}=\frac{G_{V}+G_{R}}{2}
\end{gathered}
$$

In addition to the mentioned modulus, the Young's modulus [27] which is another vital parameter characterizing the stiffness of materials, can be calculated using Equation 7.

$$
E=\frac{9 B G}{3 B+G}
$$

The calculated modulus listed in Table 4 emphasize that this compound can be predicted as a soft material. Also, brittleness of a solid can be estimated by using Pugh's ratio [28] known as $B / G$ ratio. When this ratio is higher than 1.75 known as critical value, the compound is regarded as ductile. Accordingly, it can be predicted that the $\mathrm{AgMn}{ }_{2} \mathrm{Se}_{4}$ compound is ductile as the calculated ratio is greater than this critical value. Also, the information about the compressibility of a material can be provided from Poisson's ratio $(\sigma)$ [27] which can be calculated using Equation 8. Since the ratio calculated according to the given formula is less than 0.5 , it is an indication that our compound has an almost compressible character. Moreover, the same ratio can give bonding type information of a crystal. This ratio is around 0.25 for crystals with ionic character, while this value is 0.1 for solids with covalent atomic bonding type [29-30]. In this respect, the system in this study can be regarded as ionic nature.

$$
\sigma=\frac{3 B-2 G}{6 B+2 G}
$$

Table 4. The predicted bulk $(B)$, Young's $(E)$ and shear $(G)$ modulus, Pugh's $(B / G)$ and Poisson's $(\sigma)$ ratios and anisotropy shear factor $(A)$ of $\mathrm{AgMn}_{2} \mathrm{Se}_{4}$ compound.

\begin{tabular}{ccccccccc}
\hline Compound & $B(G P a)$ & $G_{v}(G P a)$ & $G_{R}(G P a)$ & $G_{H}(G P a)$ & $E(G P a)$ & $B / G$ & $\sigma$ & $A$ \\
\hline $\mathrm{AgMn}_{2} \mathrm{Se}_{4}$ & 59.90 & 17.62 & 14.99 & 16.30 & 44.84 & 3.673 & 0.375 & 2.297
\end{tabular}

For a solid, another crucial parameter is the anisotropy shear factor [31] which can be calculated from the elastic constants as given in Equation 9. As seen in Table 4, the calculated anisotropy shear factor shows that this material has anisotropic nature in mechanically.

$$
A=\frac{2 C_{44}}{C_{11}-C_{12}}
$$

\section{Conclusion}

In this computational study, the half-metallic character in the most stable magnetic phase of chalcospinel manganese-based $\mathrm{AgMn}_{2} \mathrm{Se}_{4}$ selenide conforming to $F d \overline{3} m$ space group and 227 space number, was analyzed in detail. For different type magnetic orders, the formation energies were calculated and the energy-volume graphics were plotted. The obtained energy values emphasize that, the magnetic character of this chalcospinel system is ferromagnetic. Also, the chosen material for this study has nearly half-metallic character due to having a small band gap $\left(\mathrm{E}_{\mathrm{g}}=0.09 \mathrm{eV}\right)$ in minority spin channel in the 
calculated band structure within GGA approach. The observed half-metallic character of new chalcospinel manganese-based selenide $\left(\mathrm{AgMn}_{2} \mathrm{Se}_{4}\right)$ is promising to use in some possible spintronic applications. Furthermore, as a result of the calculations, it is concluded that this compound is a ductile material. In addition to half-metallicity, this feature is an indication that this material can be used easily in technological applications.

\section{Author Statement}

Author 1 Aytaç Erkişi: Investigation, Original Draft Writing.

Author 2 Gökhan Sürücü: Investigation, Validation, Review and Editing.

\section{Acknowledgment}

This research was supported by the Pamukkale University Research Project Unit [project number 2019BSP013].

\section{Conflict of Interest}

As the authors of this study, we declare that we do not have any conflict of interest statement.

\section{Ethics Committee Approval and Informed Consent}

As the authors of this study, we declare that we do not have any ethics committee approval and/or informed consent statement.

\section{References}

[1] I. Efthimiopoulos, Z. T. Y. Liu, S. V. Khare, P. Sarin, V. Tsurkan, A. Loidl, D. Popov, and Y. Wang "Structural transition in the magnetoelectric $\mathrm{ZnCr}_{2} \mathrm{Se}_{4}$ spinel under pressure," Phys. Rev. B, 93, 174103, 2016.

[2] C. J. Fennie and K. M. Rabe, "Polar phonons and intrinsic dielectric response of the ferromagnetic insulating spinel $\mathrm{CdCr}_{2} \mathrm{~S}_{4}$ from first principles," Phys. Rev. B, 72, 214123, 2005.

[3] H. Sims, K. Ramasamy, W. H. Butler, and A. Gupta "Electronic structure of magnetic semiconductor $\mathrm{CdCr}_{2} \mathrm{Te}_{4}$ : A possible spin-dependent symmetry filter," Appl. Phys. Lett., 103, 192402, 2013.

[4] A. S. Cameron, Y. V. Tymoshenko, P. Y. Portnichenko, J. Gavilano, V. Tsurkan, V. Felea, A. Loidl, S. Zherlitsyn, J. Wosnitza, and D. S. Inosov, "Magnetic phase diagram of the helimagnetic spinel compound $\mathrm{ZnCr}_{2} \mathrm{Se}_{4}$ revisited by small-angle neutron scattering," J. Phys. Condens. Matter., 28, $146001,2016$.

[5] N. Menyuk, K. Dwight, and R. J. Arnott, "Ferromagnetism in $\mathrm{CdCr}_{2} \mathrm{Se}_{4}$ and $\mathrm{CdCr}_{2} \mathrm{~S}_{4}$," J. Appl. Phys., 37, 1387-1388, 1966.

[6] M. Tachibana, N. Taira, and H. Kawaji, "Heat capacity and thermal expansion of $\mathrm{CdCr}_{2} \mathrm{Se}_{4}$ and $\mathrm{CdCr}_{2} \mathrm{~S}_{4}$," Solid State Commun., 151, 1776-1779, 2011.

[7] S. Kitani, M. Tachibana, and H. Kawaji, "Spin-glass-like behavior in ferromagnetic phase of $\mathrm{CdCr}_{2} \mathrm{~S}_{4}$," Solid State Commun., 179, 16-19, 2014.

[8] K. Ramasamy, D. Mazumdar, R. D. Bennett, and A. Gupta, "Syntheses and magnetic properties of $\mathrm{Cr}_{2} \mathrm{Te}_{3}$ and $\mathrm{CuCr}_{2} \mathrm{Te}_{4}$ nanocrystals," Chem. Commun., 48, 5656-5658, 2012.

[9] T. Kanomata, H. Ido, and T. Kaneko, "Effect of pressure on Curie temperature of calcogenide spinels $\mathrm{CuCr}_{2} \mathrm{X}_{4}(\mathrm{X}=\mathrm{S}$, Se and Te),” J. Phys. Soc. Jpn., 29, 332-335, 1970.

[10] T. Suzuyama, J. Awaka, H. Yamamoto, S. Ebisu, M. Ito, T. Suzuki, T. Nakama, K. Yagasaki, and S. J. Nagata, "Ferromagnetic-phase transition in the spinel-type $\mathrm{CuCr}_{2} \mathrm{Te}_{4}$," Solid State Chem., 179, 140-144, 2006.

[11] R. Li, C. Zhang, and Y. Zhang, "Critical properties of the 3D-Heisenberg ferromagnet $\mathrm{CuCr}_{2} \mathrm{Te}_{4}$," Solid State Commun., 152, 173-176, 2012.

[12] W. Kohn and L.J. Sham, "Self-consistent equations including exchange and correlation effects," Phys. Rev. A, 140, A1133-A1138, 1965.

[13] P. Hohenberg and W. Kohn, "Inhomogeneous Electron Gas,” Phys. Rev., 136, B864-B871, 1964. 
[14] P.E. Blöchl, "Projector augmented-wave method," Phys. Rev. B, 50, 17953-17979, 1994.

[15] G. Kresse and J. Hafner, "Ab initio molecular dynamics for liquid metals," Phys. Rev. B, 47, 558561, 1993.

[16] G. Kresse and J. Furthmuller, "Efficiency of ab initio total energy calculations for metals and semiconductors using a plane-wave basis set," Comput. Mater. Sci., 6, 15-50, 1996.

[17] J. P. Perdew, K. Burke, and M. Ernzerhof, “Generalized gradient approximation made simple,” Phys. Rev. Lett, 77, 3865-3868, 1996.

[18] H. J. Monkhorst and J. D. Pack, "Special points for Brillouin-zone integrations," Phys. Rev. B, 13, 5188-5192, 1976.

[19] C. Kaderoglu, G. Surucu, and A. Erkisi, "The investigation of electronic, elastic and vibrational properties of an interlanthanide perovskite: $\mathrm{PrYbO}_{3}$," J. Electronic Materials, 46, 5827-5836, 2017.

[20] P. Vinet, J. H. Rose, J. Ferrante, and J. R. Smith, "Universal Features of the Equation of State of Solids," J. Phys.: Condens. Matter, 1, 1941, 1969.

[21] Y. L. Page, and P. Saxe, "Symmetry-general least-squares extraction of elastic coefficients from ab initio total energy calculations," Phys. Rev. B, 63, 174103, 2001.

[22] F. Mouhat and F. X. Coudert, "Necessary and sufficient elastic stability conditions in various crystal systems," Phys. Rev. B, 90, 224104, 2014.

[23] D. G. Pettifor, "Theoretical predictions of structure and related properties of intermetallics." Mater. Sci. Technol., 8, 345-349, 1992.

[24] W. Voigt, Lehrbuch der Kristallphysik. B. G. Teubner, Leipzig und Berlin, 1928.

[25] A. Reuss, "Berechnung der fliessgrenze von mischkristallen auf grund der plastizitatsbedingung fur einkristalle," J. Appl. Math. Mech., 9, 49-58, 1929.

[26] R. Hill, "The elastic behavior of a crystalline aggregate," Proc. Phys. Soc., A 65, 349-354, 1952.

[27] D. H. Wu, H. C. Wang, L.T. Wei, R. K. Pan, and B. Y. Tang, "First-principles study of structural stability and elastic properties of $\mathrm{MgPd}_{3}$ and its hydride," J. Magnes. Alloy., 2, 165-174, 2014.

[28] S.F. Pugh, "XCII. Relations between the elastic moduli and the plastic properties of polycrystalline pure metals," Lond. Edinb. Dubl. Phil. Mag., 45, 823-843, 1954.

[29] G. Surucu, "Investigation of structural, electronic, anisotropic elastic, and lattice dynamical properties of MAX phases borides: An Ab-inito study on hypothetical $\mathrm{M}_{2} \mathrm{AB}(\mathrm{M}=\mathrm{Ti}, \mathrm{Zr}, \mathrm{Hf} ; \mathrm{A}=$ Al, Ga, In) compounds," Mater. Chem. Phys., 203, 106-117, 2018.

[30] V. V. Bannikov, I. R. Shein, and A. L. Ivanovskii, "Electronic structure, chemical bonding and elastic properties of the first thorium-containing nitride perovskite $\mathrm{TaThN}_{3}$," Phys. Status. SolidiRapid. Res. Lett., 1, 89-91, 2007.

[31] K. Lau and A. K. McCurdy, "Elastic anisotropy factors for orthorhombic, tetragonal, and hexagonal crystals," Phys. Rev. B, 58, 8980-8984, 1998. 